\begin{tabular}{cc|c}
\hline Tar. Bil. Der. & Journal of Agricultural Sciences \\
& $\begin{array}{c}\text { Dergi web sayfası: } \\
\text { www.agri.ankara.edu.tr/dergi }\end{array}$ & Journal homepage: \\
& www.agri.ankara.edu.tr/journal
\end{tabular}

\title{
Nutritive Value of Sunflower Silages Ensiled with Corn or Alfalfa at Different Rate
}

\author{
Mustafa TAN ${ }^{\mathrm{a}}$, Halil YOLCU ${ }^{\mathrm{b}}$, Zeynep DUMLU GUL ${ }^{\mathrm{a}}$ \\ a Atatürk University, Faculty of Agriculture, Department of Field Crops, Erzurum, TURKEY \\ ${ }^{\boldsymbol{b}}$ Gümüşhane University, Kelkit Aydın Doğan Vocational Training School, Gümüşhane, TURKEY
}

\author{
ARTICLE INFO \\ Research Article \\ DOI: 10.1501/Tarimbil 0000001320 \\ Corresponding Author: Mustafa TAN, E-mail: mustan@atauni.edu.tr, Tel: +90 (442) 2312530 \\ Received: 18 February 2014, Received in Revised Form: 16 June 2014, Accepted: 23 June 2014
}

\begin{abstract}
Sunflower (Helianthus annuus L.) having shorter growing season, better cold tolerant and more drought resistant is important alternative silage plant in highlands. But it has poor silage quality. To improve the quality of sunflower silage can be mixed an appropriate amount of corn (Zea mays L.) and alfalfa (Medicago sativa L.). This research was carried out to evaluate quality characteristics of nine silage types: Sunflower, corn and alfalfa silages; plus their some mixtures silages $(75 \%$ sunflower $+25 \%$ corn, $50 \%$ sunflower $+50 \%$ corn, $25 \%$ sunflower $+75 \%$ corn, $75 \%$ sunflower $+25 \%$ alfalfa, $50 \%$ sunflower $+50 \%$ alfalfa and $25 \%$ sunflower $+75 \%$ alfalfa); at two harvest stages: Beginning of flowering for sunflower and alfalfa and milk-dough stage for corn (early stage), and end of flowering stage for sunflower and alfalfa, and dough stage for corn (late stage). The experimental design was in a factorial arrangement of randomized complete block with replicated four times. Dry matter content (DM), crude protein content (CP), neutral detergent fiber content (NDF), acid detergent fiber content (ADF), silage $\mathrm{pH}$ and physical characteristics (PC) of silages were determined in this study. Mixing of alfalfa in NDF, ADF and CP and corn in DM, pH and PC had positively effect in sunflower silages. Late stage had positively affected DM, PC and $\mathrm{pH}$ for silage. Consequently, sunflower silages mixed with corn, with the condition of not being less than $50 \%$ at late stage, are recommended for farmers.
\end{abstract}

Keywords: Sunflower; Corn; Alfalfa; Mixtures; Silage

\section{Farklı Oranlarda Yonca veya Mısır ile Karıştırılan Ayçiçeği Silajının Besin Değeri}

\section{ESER BİLGİSI}

Araştırma Makalesi

Sorumlu Yazar: Mustafa TAN, E-posta: mustan@atauni.edu.tr, Tel: +90 (442) 2312530

Geliş Tarihi: 18 Şubat 2014, Düzeltmelerin Gelişi: 16 Haziran 2014, Kabul: 23 Haziran 2014

\section{ÖZET}

Kısa gelişme süresine sahip, soğuğa ve kurağa dayanıklılı̆̆ı iyi olan ayçiçeği (Helianthus annuus L.), önemli bir alternatif silaj bitkisidir. Fakat ayçiçeğinin silaj kalitesi düşüktür. Ayçiçeği silajının kalitesini iyileştirmek için mısır 
(Zea mays L.) ve yonca (Medicago sativa L.) ile karışımlar yapılabilir. Bu çalışmada ayçiçeği, mısır ve yonca ile bunların bazı karışımlarından oluşan (\% 75 ayçiçeği $+\% 25$ misır, \% 50 ayçiçeği $+\% 50$ mısır, \% 25 ayçiçeği + $\% 75$ misır, \% 75 ayçiçeği $+\% 25$ yonca, \% 50 ayçiçeği $+\% 50$ yonca ve \% 25 ayçiçeği $+\% 75$ yonca) silajların kalite özellikleri incelenmiştir. Silajlar bitkilerin iki farklı gelişme döneminde (Erken dönem: Yonca ve ayçiçeği için çiçeklenme başlangıcı, mısır için süt olum dönemi ve Geç dönem: Yonca ve ayçiçeği için çiçeklenme sonu, mısır için hamur olum dönemi) yapılmıştır. Araştırma şansa bağlı tam bloklar deneme deseninde faktöriyel düzenlemeye göre dört tekrarlamalı olarak kurulmuştur. Silajların kuru madde oranı (DM), ham protein (CP), NDF, ADF, pH ve fiziksel özellikleri (PC) incelenmiştir. Ayçiçeği ile yonca karışımlarında NDF, ADF ve CP; mısır karışımlarında ise DM, pH ve PC yüksek bulunmuştur. Geç dönemde silaj yapıldığı zaman DM, PC ve silaj pH'sı yükselmiştir. Bu nedenle üreticilere geç gelişme döneminde ayçiçeğinin mısır ile en az \% 50 oranında zenginleştirilerek silolanması tavsiye edilebilir.

Anahtar Kelimeler: Ayçiçeği; Mısır; Yonca; Karışım; Silaj

(c) Ankara Üniversitesi Ziraat Fakültesi

\section{Introduction}

There are some problems for meeting roughage requirements of farms in Eastern Turkey during long the winters (Tavlas et al 2009). Main reasons of this problem are low forage crops cultivation and productivity (Yolcu \& Tan, 2008). Far a partial solution to this problem, silage crops growing were started in this region, since main silage crops such as corn, sunflower and sorghum produce higher dry matter yield when compared to the other forage crops for animal feeding (Guney et al 2012).

Sunflower has more tolerant to cold and drought conditions (Ozduven et al 2009) and it is less affected by frost conditions, remains longer time in the field and completes the its growing period (Guney et al 2012). Besides, sunflower has higher dry matter yield and crude protein content than that of corn (Mafakher et al 2010). However, sunflower silage has some negative features in terms of quality. The high fiber content of sunflower silage causes decreases digestibility of nutrient matters (Demirel et al 2008) and its low dry matter content at maturity stage create ensiling difficulties (Peiretti \& Meineri 2010). Besides, sunflower silage has higher $\mathrm{pH}$ (Demirel et al 2008; Mafakher et al 2010) and lower quality in terms of color, structure and smell (Guney et al 2012).

Mixtures in different rates among various silage plants not only increase silage quality but also decrease negative properties in silages. Thus, many investigations have been made related to the topic by many researchers in recently (Demirel et al 200; Zhu et al 2011; Souma et al 2011). In addition, determination of suitable harvest stages of plants used for silage also are important to increase silage quality. Influences of plants harvest stages on silage quality have been reported by many researchers (Bal et al (1997); Demirel et al 2006a; De Rezende et al 2007; Morales et al 2011).

To decrease some negative features of sunflower silage can be added the other plants such as corn and alfalfa to the silage. However, which plants and what portions to be mixed up should be known. Moreover, farmers want to know suitable harvest stages of these plants for making quality silage. Consequently, both silage types and harvest stages of plants are important factors for obtaining quality silages. For these reasons, the aim of this study was to evaluate quality characteristics of nine silage types at two different harvest stages.

\section{Material and Methods}

The study was carried out under laboratory conditions at the Field Crops Department in Ataturk University, Agriculture Faculty, in 2012. The experimental design was completely in a factorial arrangement of randomized complete block with replicated four times and treatments were nine silage types: Sunflower (Helianthus annuus L., population) (SF), corn (Zea mays L. var. OSSK-596) (C) and alfalfa (Medicago sativa L. var. Bilensoy) (A) pure, and $75 \%$ sunflower $+25 \%$ corn $(75 \mathrm{SF}-25 \mathrm{C}), 50 \%$ 
sunflower $+50 \%$ corn $(50 \mathrm{SF}-50 \mathrm{C}), 25 \%$ sunflower $+75 \%$ corn $(25 \mathrm{SF}-75 \mathrm{C}), 75 \%$ sunflower $+25 \%$ alfalfa (75SF-25A), 50\% sunflower $+50 \%$ alfalfa (50SF-50A), 25\% sunflower $+75 \%$ alfalfa (25SF$75 \mathrm{~A})$ silages and two different stages beginning of flowering for sunflower and alfalfa, and milk-dough stage for corn (early stage), and end of flowering stage for sunflower and alfalfa, and dough stage for corn (late stage). Rates of sunflower binary mixtures enriched with corn and alfalfa were determined according to weight. Sunflower, corn and alfalfa were chopped and then ensiled alone or mixture into $2.5 \mathrm{~kg}$ glass jars and four glass jars were made for each silage sample. Silages were opened to analyze for dry matter content (DM), crude protein content (CP), neutral detergent fiber content (NDF), acid detergent fiber content (ADF), silage $\mathrm{pH}$ and physical characteristics (PC) of silages after 60 days of ensiling. Dry matter content was found according to AOAC (1990). The Kjeldahl method and a Vapodest 10 Rapid Kjeldahl Distillation Unit (Gerhardt, Konigswinter, Germany) were used to determine total N (Bremner 1996) in single plants and binary mixtures silages. ADF, NDF and $\mathrm{pH}$ measurements of single plants and binary mixtures silages were found according to Akyildiz (1986), Kilic (1986) and Van Soest (1963). Physical characteristics (color, structure and smell) were determined by the Kilic's (1986) method.

Data of DM, CP, ADF, NDF, $\mathrm{pH}$ and $\mathrm{PC}$ were subjected to analysis of variance (ANOVA). The results were statistically evaluated by using MSTAT-C statistical computer package software program and mean separations were made on the basis of least significant differences test (LSD).

\section{Results and Discussion}

Significant differences $(\mathrm{P}<0.01)$ were found in terms of DM among silage types at early stage, late stage and over harvest stages (Table 1). Similar DM variation among silage types were shown by other researchers (Demirel et al 2006b; Demirel et al 2008; Contreras-Govea et al 2009).

The higher dry matters were obtained from pure C silage $(27.42 \%)$, followed by pure A $(24.44 \%)$,
Table 1- Dry matter contents of sunflower silages enriched with corn and alfalfa at different growth stages (\%)

Çizelge 1- Değişik gelişme dönemlerinde misır veya yonca ile zenginleştirilmiş ayçiçeği silajlarının kuru madde oranlart (\%)

\begin{tabular}{llll}
\hline Silage type & Early stage $^{a}$ & Late stage $^{b}$ & Mean \\
\hline Sunflower (SF) & $21.13 \mathrm{bc}$ & $27.97 \mathrm{bc}$ & $24.55 \mathrm{c}$ \\
75SF-25C & $19.71 \mathrm{c}$ & $30.14 \mathrm{ab}$ & $24.93 \mathrm{c}$ \\
50SF-50C & $21.81 \mathrm{bc}$ & $31.25 \mathrm{a}$ & $26.53 \mathrm{bc}$ \\
25SF-75C & $23.90 \mathrm{~b}$ & $31.79 \mathrm{a}$ & $27.85 \mathrm{~b}$ \\
Corn (C) & $27.42 \mathrm{a}$ & $32.58 \mathrm{a}$ & $30.00 \mathrm{a}$ \\
75SF-25A & $21.14 \mathrm{bc}$ & $28.26 \mathrm{bc}$ & $24.70 \mathrm{c}$ \\
50SF-50A & $23.91 \mathrm{~b}$ & $27.11 \mathrm{c}$ & $25.51 \mathrm{c}$ \\
25SF-75A & $23.17 \mathrm{bc}$ & $27.54 \mathrm{bc}$ & $25.35 \mathrm{c}$ \\
Alfalfa (A) & $24.44 \mathrm{ab}$ & $25.57 \mathrm{c}$ & $25.01 \mathrm{c}$ \\
\hline Mean & $22.96 \mathrm{~b}$ & $29.13 \mathrm{a}$ & 26.05 \\
\hline
\end{tabular}

Silage type $\mathrm{x}$ harvest stage interaction LSD: $3.61^{* *}$

Values followed by different letters in a column represent significant differences; **, $\mathrm{P}<0.01$; a, beginning of flowering stage for sunflower and alfalfa and milk-dough stage for corn; $\mathrm{b}$, end of flowering stage for sunflower and alfalfa and dough stage for corn

50SF-50A (23.91\%) and 25SF-75C (23.90\%) silages at early stage. The higher dry matters among silage types were found in pure $\mathrm{C}$ silages $(32.58 \%)$ followed by $25 \mathrm{SF}-75 \mathrm{C}(31.79 \%)$ and 50SF-50C (31.25\%) silages at late stage. Significant differences were determined among silage types over harvest stages. Corn silage had the highest DM $(30.00 \%)$ followed by $25 \mathrm{SF}-75 \mathrm{C}(27.85 \%)$ silages, whereas all the other silages gave similar DM over harvest stages. Dry matter contents of grasses are higher than those of legumes and sunflower (Guney et al 2012; Dumlu \& Tan, 2009). Therefore, dry matter contents were found as high value in a pure corn silage and mixtures silage that have high rate corn. There was difference $(\mathrm{P}<0.01)$ among harvest stages in terms of the DM over silage types. This is in agreement with the results of $\mathrm{Bal}$ (2006), Demirel et al (2006a) and De Rezende et al (2007), who reported that harvest times affected DM of silages. Late stage gave higher DM (29.13\%) than that of early stage $(22.96 \%)$ (Table 1$)$. It is an expected 
result that dry matter contents increase with the advancement of ripening in plants. Silage type $x$ harvest stage interaction was important in DM. This relation was shown in Figure 1.

There were significant differences in terms of $\mathrm{CP}$ content among silage types at early stage $(\mathrm{P}<0.01)$, late stage $(\mathrm{P}<0.05)$ and over harvest stages $(\mathrm{P}<$ 0.01) (Table 2). Similar findings were also reported in terms of $\mathrm{CP}$ among different silage types in other studies (Demirel et al 2006b; Demirel et al 2008; Mafakher et al 2010). Pure alfalfa silage and SF silages enriched with A produced higher $\mathrm{CP}$ content than the other silages at early stage, late stage and over harvest stages. Pure alfalfa, 50SF-50A, 75SF25A and 25SF-75A silages gave 17.95, 16.57, 16.55 and $15.94 \% \mathrm{CP}$ content at early stage, respectively. Also at late stage, pure A silage (14.58\%), 25SF75A (15.47\%), 50SF-50A (14.37\%) and 75SF-25A $(12.95 \%)$ silages had greater $\mathrm{CP}$ content than the other silages. Likewise, pure A silage, 25SF-75A, 50SF-50A and 75SF-25A silages produced 16.27 , $15.70,15.47$ and $14.75 \%$ CP content over harvest stage, respectively. It is an expected result that silage of alfalfa legume had greater crude protein content than corn and sunflower silages. Therefore, crude protein contents of silages including alfalfa were high.

Differences $(\mathrm{P}<0.01)$ were determined among harvest stages in terms of $\mathrm{CP}$ content over silage types. This result is in agreement with statement of De Rezende et al (2007), reported that sunflower cultivars harvested at 95-110 days after sowing had differences in terms of CP. Moreover, Bal (2006) determined that whole plant corn silages harvested at 3 different stages of maturity had differences in terms of CP. Early stage (14.32\%) had higher CP content than that of late stage $(12.58 \%)$ over silage type (Table 2).

ADF and NDF contents of the silage types were significantly $(\mathrm{P}<0.01)$ different at early stage, late stage and over harvest stages (Table 3 and 4). Similarly, Contreras-Govea et al (2006), Contreras-Govea et al (2009) and Guney et al (2012) found that different silage types had

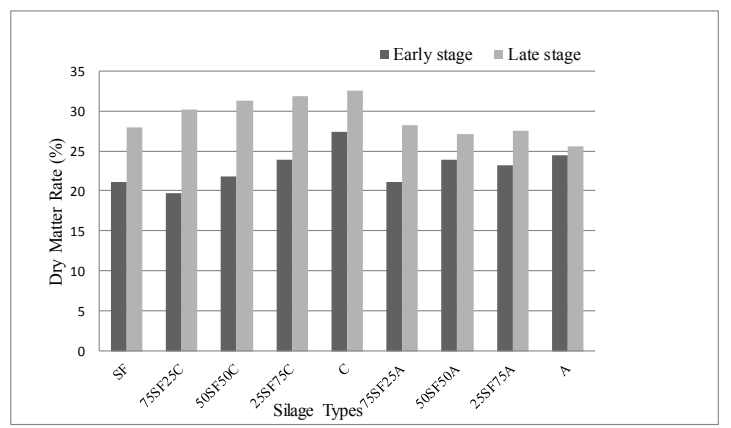

Figure 1- Silage type $x$ growth stage interaction in dry matter content of sunflower silages enriched with corn and alfalfa at different stages

Şekil 1- Silaj tipi x gelişme dönemi interaksiyonunun misır veya yonca ile zenginleştirilmiş ayçiçeği silajlarinda kuru madde oranina etkileri

Table 2- Crude protein contents of sunflower silages enriched with corn and alfalfa at different stages (\%)

Çizelge 2- Değişik gelişme dönemlerinde misır veya yonca ile zenginleştirilmiş ayçiçeği silajlarının ham protein oranlart (\%)

\begin{tabular}{llll}
\hline Silage type & Early stage $^{a}$ & Late stage $^{b}$ & Mean \\
\hline Sunflower (SF) & $13.54 \mathrm{c}$ & $11.60 \mathrm{~cd}$ & $12.57 \mathrm{c}$ \\
75SF-25C & $13.46 \mathrm{c}$ & $12.66 \mathrm{c}$ & $13.06 \mathrm{c}$ \\
$50 \mathrm{SF}-50 \mathrm{C}$ & $13.74 \mathrm{bc}$ & $12.49 \mathrm{c}$ & $13.12 \mathrm{c}$ \\
25SF-75C & $10.97 \mathrm{~d}$ & $10.11 \mathrm{de}$ & $10.54 \mathrm{~d}$ \\
Corn (C) & $10.16 \mathrm{~d}$ & $9.04 \mathrm{e}$ & $9.60 \mathrm{~d}$ \\
75SF-25A & $16.55 \mathrm{a}$ & $12.95 \mathrm{bc}$ & $14.75 \mathrm{~b}$ \\
50SF-50A & $16.57 \mathrm{a}$ & $14.37 \mathrm{ab}$ & $15.47 \mathrm{ab}$ \\
25SF-75A & $15.94 \mathrm{ab}$ & $15.47 \mathrm{a}$ & $15.70 \mathrm{ab}$ \\
Alfalfa (A) & $17.95 \mathrm{a}$ & $14.58 \mathrm{a}$ & $16.27 \mathrm{a}$ \\
\hline Mean & $14.32 \mathrm{a}$ & $12.58 \mathrm{~b}$ & 13.45 \\
\hline
\end{tabular}

Silage type $\mathrm{x}$ harvest stage interaction: $\mathrm{ns}$

Values followed by different letters in a column represent significant differences; ns, no significant; a, beginning of flowering stage for sunflower and alfalfa and milk-dough stage for corn; $b$, end of flowering stage for sunflower and alfalfa and dough stage for corn

variation in terms of $\mathrm{ADF}$ and NDF. In addition, Demirel et al (2008) reported that silage types had differences in NDF. Pure alfalfa silage produced the lowest ADF content (26.94\%) followed by 
pure C silage (28.65\%) and 25SF-75A (28.69\%) at early stage (Table 3 ). Also at late stage, pure alfalfa (29.88\%), pure C (31.80\%), 25SF-75A (32.56\%) and 50SF-50A $(33.32 \%)$ silages had the lower ADF contents than the others. Similarly, the lowest ADF content was found pure A silage (28.41\%) followed by pure C silage (30.23\%) and 25SF-75A silage $(30.62 \%)$, whereas the other silages gave the highest ADF content over harvest stages. Pure alfalfa $(41.73 \%), 25 \mathrm{SF}-75 \mathrm{~A}(48.35 \%)$ and 50SF50A (50.27\%) silages contained lower NDF than other silages at early stage (Table 4). Also at late stage, pure alfalfa silage $(43.19 \%), 25 \mathrm{SF}-75 \mathrm{~A}$ $(50.43 \%)$ and 50SF-50A (51.91\%) silages included the lower NDF contents than those of the others. Similarly, the lowest NDF content was found pure A silage (42.46\%) followed by $25 \mathrm{SF}-75 \mathrm{~A}(49.39 \%)$ and $50 \mathrm{SF}-50 \mathrm{~A}(51.09 \%)$ silages, whereas the other silages had similar or higher NDF contents over harvest stages. Harvest stages had different

Table 3- Acid detergent fiber contents of sunflower silages enriched with corn and alfalfa at different stages (\%)

Çizelge 3- Değişik gelişme dönemlerinde musır veya yonca ile zenginleştirilmiş ayçiçeği silajlarının ADF oranlart (\%)

\begin{tabular}{llll}
\hline Silage type & Early stage $^{a}$ & Late stage $^{b}$ & Mean \\
\hline Sunflower (SF) & $37.81 \mathrm{a}$ & $43.09 \mathrm{a}$ & $40.44 \mathrm{a}$ \\
75SF-25C & $34.28 \mathrm{bc}$ & $38.21 \mathrm{~b}$ & $36.24 \mathrm{~b}$ \\
$50 \mathrm{SF}-50 \mathrm{C}$ & $32.13 \mathrm{~cd}$ & $36.21 \mathrm{bc}$ & $34.17 \mathrm{c}$ \\
25SF-75C & $31.59 \mathrm{c}-\mathrm{e}$ & $34.42 \mathrm{~cd}$ & $33.01 \mathrm{c}$ \\
Corn (C) & $28.65 \mathrm{ef}$ & $31.80 \mathrm{ef}$ & $30.23 \mathrm{~d}$ \\
$75 \mathrm{SF}-25 \mathrm{~A}$ & $35.20 \mathrm{ab}$ & $38.56 \mathrm{~b}$ & $36.88 \mathrm{~b}$ \\
50SF-50A & $31.82 \mathrm{~cd}$ & $33.32 \mathrm{de}$ & $32.57 \mathrm{c}$ \\
25SF-75A & $28.69 \mathrm{ef}$ & $32.56 \mathrm{~d}-\mathrm{f}$ & $30.62 \mathrm{~d}$ \\
Alfalfa (A) & $26.94 \mathrm{f}$ & $29.88 \mathrm{f}$ & $28.41 \mathrm{e}$ \\
\hline Mean & $31.90 \mathrm{~b}$ & $35.34 \mathrm{a}$ & 33.62 \\
\hline
\end{tabular}

Silage type $\mathrm{x}$ harvest stage interaction: $\mathrm{ns}$

Values followed by different letters in a column represent significant differences; ns, no significant; a, beginning of flowering stage for sunflower and alfalfa and milk-dough stage for corn; $b$, end of flowering stage for sunflower and alfalfa and dough stage for corn
$(\mathrm{P}<0.01)$ in terms of ADF and NDF contents over silage types. This result is in agreement with the report of Demirel et al (2006a), who stated that sunflowers harvested at different stages had variation in terms of ADF and NDF. AF and NDF contents of the early stage were lower than those of the late stage (Table 3 and 4). This is a natural consequence of the increase fiber structure with increasing maturity in plants.

Significant variation had among the silage types in terms of silage $\mathrm{pH}$ at early stage $(\mathrm{P}<0.01)$ late stage $(\mathrm{P}<0.01)$ and over harvest stages $(\mathrm{P}<0.01)$ (Table 5). Similarly, Demirel et al (2006b), Demirel et al (2008) and Mafakher et al (2010) reported that there were differences in terms of $\mathrm{pH}$ among different silage types. Pure corn silage and SF silages mixtured $\mathrm{C}$ had the lower $\mathrm{pH}$ than those of the others at early stage and late stage. Silage $\mathrm{pH}$ of pure C, 50SF-50C, 25SF-75C and 75SF-25C silages were resulted in $4.36,4.38,4.47$ and 4.92

Table 4- Neutral detergent fiber contents of sunflower silages enriched with corn and alfalfa at different stages (\%)

Çizelge 4- Değişik gelişme dönemlerinde misır veya yonca ile zenginleştirilmiş ayçiçeği silajlarının NDF oranlart (\%)

\begin{tabular}{llll}
\hline Silage type & Early stage $^{a}$ & Late stage $^{b}$ & Mean \\
\hline Sunflower (SF) & $55.85 \mathrm{a}$ & $57.62 \mathrm{a}$ & $56.73 \mathrm{a}$ \\
$75 \mathrm{SF}-25 \mathrm{C}$ & $54.14 \mathrm{ab}$ & $55.75 \mathrm{a}-\mathrm{c}$ & $54.94 \mathrm{a}$ \\
$50 \mathrm{SF}-50 \mathrm{C}$ & $52.32 \mathrm{bc}$ & $53.00 \mathrm{c}-\mathrm{e}$ & $52.66 \mathrm{~b}$ \\
$25 \mathrm{SF}-75 \mathrm{C}$ & $51.89 \mathrm{bc}$ & $53.47 \mathrm{~cd}$ & $52.68 \mathrm{~b}$ \\
Corn $(\mathrm{C})$ & $52.07 \mathrm{bc}$ & $53.65 \mathrm{~b}-\mathrm{d}$ & $52.86 \mathrm{~b}$ \\
$75 \mathrm{SF}-25 \mathrm{~A}$ & $55.45 \mathrm{a}$ & $56.36 \mathrm{ab}$ & $55.91 \mathrm{a}$ \\
50SF-50A & $50.27 \mathrm{~cd}$ & $51.91 \mathrm{de}$ & $51.09 \mathrm{bc}$ \\
25SF-75A & $48.35 \mathrm{~d}$ & $50.43 \mathrm{e}$ & $49.39 \mathrm{c}$ \\
Alfalfa (A) & $41.73 \mathrm{e}$ & $43.19 \mathrm{f}$ & $42.46 \mathrm{~d}$ \\
\hline Mean & $51.34 \mathrm{~b}$ & $52.82 \mathrm{a}$ & 52.08 \\
\hline
\end{tabular}

Silage type $\mathrm{x}$ harvest stage interaction: $\mathrm{ns}$

Values followed by different letters in a column represent significant differences; ns, no significant; a, beginning of flowering stage for sunflower and alfalfa and milk-dough stage for corn; $b$, end of flowering stage for sunflower and alfalfa and dough stage for corn 
$\mathrm{pH}$ at early stage and 4.12, 4.23, 4.28 and 4.69 $\mathrm{pH}$ at late stage, respectively. Similarly, also over harvest stages, pure C (4.24), 50SF-50C (4.30), 25SF-75C (4.38) and 75SF-25C (4.80) had lower $\mathrm{pH}$ than those of the others. Silage $\mathrm{pH}$ in pure corn silage and mixture silages that have a high rate of corn were found in low value due to corn containing more dry matter content and soluble carbohydrate. Among harvest stages, there were also differences in $\mathrm{pH}$ over silage types (Table 5). This result is in agreement with reports of Demirel et al (2006a), Bal (2006) and De Rezende et al (2007), who stated that there were differences in terms of silage $\mathrm{pH}$ among harvest stages. Late stage had lower $\mathrm{pH}$ (4.74) than that of early stage (5.13). Because accumulation of soluble carbohydrates increased with maturity advancement, fermentation may be easy at late stage. Eventually, silage $\mathrm{pH}$ might be decrease at late stage in the research.

Silages in terms of quality determining according to physical characteristics had important variation at early stage and late stage (Table 6). The greatest quality was found in a pure $\mathrm{C}$ silage (Supreme) followed by 25SF-75C (Medium), 50SF50C (Low), 75SF-25A (Low), 75SF-25C (Low) and 50SF-50A (Low) at early stage. Similarly, also at late stage, the highest quality was determined in pure C silage (Supreme) followed by $25 \mathrm{SF}-75 \mathrm{C}$ (Good) and 50SF-50C (Medium). The other silages were low quality.

Table 5- Silage pH of sunflower silages enriched with corn and alfalfa at different stages

Çizelge 5- Değişik gelişme dönemlerinde misır veya yonca ile zenginleştirilmiş ayçiçeği silajlarının $\mathrm{pH}$ değerleri

\begin{tabular}{llll}
\hline Silage type & Early stage $^{a}$ & Late stage $^{b}$ & Mean \\
\hline Sunflower (SF) & $5.32 \mathrm{a}-\mathrm{c}$ & $4.83 \mathrm{a}-\mathrm{c}$ & $5.08 \mathrm{bc}$ \\
75SF-25C & $4.92 \mathrm{c}$ & $4.69 \mathrm{bc}$ & $4.80 \mathrm{c}-\mathrm{e}$ \\
50SF-50C & $4.38 \mathrm{c}$ & $4.23 \mathrm{c}$ & $4.30 \mathrm{e}$ \\
25SF-75C & $4.47 \mathrm{c}$ & $4.28 \mathrm{c}$ & $4.38 \mathrm{de}$ \\
Corn (C) & $4.36 \mathrm{c}$ & $4.12 \mathrm{c}$ & $4.24 \mathrm{e}$ \\
75SF-25A & $5.19 \mathrm{bc}$ & $4.85 \mathrm{a}-\mathrm{c}$ & $5.02 \mathrm{~b}-\mathrm{d}$ \\
50SF-50A & $5.23 \mathrm{a}-\mathrm{c}$ & $5.10 \mathrm{ab}$ & $5.17 \mathrm{bc}$ \\
25SF-75A & $6.27 \mathrm{a}$ & $5.50 \mathrm{a}$ & $5.88 \mathrm{a}$ \\
Alfalfa (A) & $6.04 \mathrm{ab}$ & $5.09 \mathrm{ab}$ & $5.56 \mathrm{ab}$ \\
\hline Mean & $5.13 \mathrm{a}$ & $4.74 \mathrm{~b}$ & 4.94
\end{tabular}

Silage type $\mathrm{x}$ harvest stage interaction: $\mathrm{ns}$

Values followed by different letters in a column represent significant differences; ns, no significant; a, beginning of flowering stage for sunflower and alfalfa and milk-dough stage for corn; $b$, end of flowering stage for sunflower and alfalfa and dough stage for corn

Table 6- Physical characteristics (color, smell and structure) of sunflower silages enriched with corn and alfalfa at different stages

Çizelge 6- Değişik gelişme dönemlerinde misır veya yonca ile zenginleştirilmiş ayçiçeği silajlarının fiziksel özellikleri (renk, koku ve doku)

\begin{tabular}{ccccccccccc}
\hline \multirow{2}{*}{ Silage type } & \multicolumn{9}{c}{ Early stage $^{a}$} & \multicolumn{7}{c}{ Late stage $^{a}$} \\
\cline { 2 - 11 } & Color & Smell & Structure & Total & Quality & Color & Smell & Structure & Total & Quality \\
\hline SF & 0 & 2 & 2 & 4 & Bad & 0 & 4 & 3 & 7 & Low \\
75SF-25C & 1 & 3 & 2 & 6 & Low & 1 & 4 & 3 & 8 & Low \\
50SF-50C & 1 & 4 & 4 & 9 & Low & 2 & 6 & 4 & 12 & Medium \\
25SF-75C & 1 & 8 & 4 & 13 & Medium & 2 & 8 & 4 & 14 & Good \\
C & 2 & 14 & 4 & 20 & Supreme & 2 & 14 & 4 & 20 & Supreme \\
75SF-25A & 1 & 4 & 3 & 8 & Low & 2 & 4 & 3 & 9 & Low \\
50SF-50A & 0 & 3 & 2 & 5 & Low & 2 & 4 & 3 & 9 & Low \\
25SF-75A & 0 & 2 & 2 & 4 & Bad & 1 & 3 & 3 & 7 & Low \\
A & 0 & 2 & 1 & 3 & Bad & 0 & 3 & 3 & 6 & Low \\
\hline
\end{tabular}

a, beginning of flowering stage for sunflower and alfalfa and milk-dough stage for corn; $b$, end of flowering stage for sunflower and alfalfa and dough stage for corn 


\section{Conclusions}

Since the quality of silage types changes according to the harvest stage of plants used for silage, ideal harvest stages should be determined first in the results. In spite of the fact that late stage had higher ADF and NDF and lower CP than the early stage, it was found to be more appropriate because of greater DM and better physical characteristics, and lower $\mathrm{pH}$ for quality silage. Superiority of corn silage was apparent according to the results of the research. But, our aim in this study was to increase quality of sunflower silage with the addition of plants such as corn and alfalfa. In this context, while sunflower silages enriched with alfalfa were superior in terms of ADF, NDF and CP, sunflower silages enriched with corn had superior properties in DM and physical characteristics. Additionally sunflower silages mixed with alfalfa have high silage $\mathrm{pH}$, it is not desirable. Consequently, sunflower binary mixtures silages enriched by corn with a condition of not being less than fifty percent at late stage, can be preferred for animal feeding in the regions where there are problems in corn cultivation.

\section{References}

Akyildiz R (1986). Feed Science and Technology. Ankara University Agriculture Faculty Publications, No: 974, Text Book No: 286, Ankara. pp. 411

AOAC (1990). Association of official analytical chemistry. Official Methods of Analysis. 15 ${ }^{\text {th }}$ Edn. Vol.1, Washington, D.C

Bal M A, Coors J G \& Shaver R D (1997). Impact of the maturity of corn for use as silage in the diets of dairy cows on intake,digestion, and milk production. Journal of Dairy Science 80: 2497-2503

Bal M A (2006). Effect of hybrid type, stage of maturity, and fermentation length on whole plant corn silage quality. Turkish Journal of Veterinary and Animal Science 30: 331-336

Bremner J M (1996). Nitrogen-total In: Methods of Soil Analysis Part III (Bartels, J.M., and Bigham, J.M., eds.). ASA SSSA Publ. Agron. No: 5 Madison WI, USA, pp. 1085-1121

Contreras-Govea F E, Albrecht K A \& Muck R E (2006). Spring yield and silage characteristics of kura clover, winter wheat, and in mixtures. Agronomy Journal 98: 781-787

Contreras-Govea F E, Muck R E, Armstrong K L \& Albrecht K A (2009). Nutritive value of corn silage in mixture with climbing beans. Animal Feed Science and Technology 150: 1-8

Demirel M, Bolat D, Celik S, Bakici Y \& Celik S (2006a). Quality of silages from sunflower harvested at different vegetational stages. JAAR 30: 161-165

Demirel M, Bolat D, Celik S, Bakici Y \& Tekeli A(2006b). Evaluation of fermentation qualities and digestibilities of silages made from sorghum and sunflower alone and the mixtures of sorghum-sunflower. Journal of Biological Science 6: 926-930

Demirel M, Bolat D, Celik S, Bakici Y \& Eratak S (2008). Determination of fermentation and digestibility characteristics of corn, sunflower and combination of corn and sunflower silages. Journal of Animal and Veterinary Advences 7: 707-711

Demirel M, Celik S, Temur C, Güney M \& Celik S (2009). Determination of fermentation properties and digestibility characteristics of combination of cornsoybean and corn silages. Journal of Animal and Veterinary Advances 8: 711-714

De Rezende A V, Evangelista A R, Valeriano A R, Siqueira G R, Vilela H H \& Lopes J (2007). Nutritive value of six cultivars of sunflower silages at different cutting ages. Ciencia e Agrotecnologia 31: 896-902

Dumlu Z \& Tan M (2009). Determination of silage value of some legumes and mixtures in Erzurum conditions. Journal of Ataturk University Agricultural Faculty 40(2): 15-21

Guney E, Tan M \& Yolcu H (2012). Yield and quality characteristics of some confectionery and oilseed sunflower genotypes for silage in highlands. Turkish Journal of Field Crops 17: 31-34

Kilic A (1986). Teaching Silage Feed (Teaching, Education And Practice Recommendations), Bilgehan Printinghouse, Bornova, İzmir

Mafakher E, Meskarbashee M, Hassibi P \& Mashayekhi M R (2010). Study of chemical composition and quality characteristics of corn, sunflower and cornsunflower silages. Asian Journal of Animal and Veterinary Advances 5: 175-179

Morales J U, Alatorre J A H, Escalante A A, Lopez S B, Vazquez H G \& Gomez M O D (2011). Nutritional characteristics of silage and hay of pearl millet at four 
phenological stages. Journal of Animal and Veterinary Advances 10: 1378-1382

Ozduven M L, Koc F, Polat C \& Coskuntuna L (2009). The effects of lactic acid bacteria and enzyme mixture inoculants on fermentation and nutrient digestibility of sunflower silage. Journal of Kafkas University Veterinary Faculty 15: 195-199

Peiretti P G \& Meineri G (2010). Evolution of chemical composition, nutritive value and fatty acid content of sunflower (Helianthus annuus L.) during the growth cycle. Journal of Animal and Veterinary Advences 9: 112-117

Souma K, Wang P, Kanda F, Igarashi H \& Masuko T (2011). Influences of combination feeding of high moisture low quality grass-dominant mixture silage with corn silage on nutritive value and feed intake in sheep. Grassland Science 57: 18-22

Tavlas A, Yolcu H \& Tan M (2009). Yields and qualities of some red clover (Trifolium pratense L.) genotypes in crop improvement systems as livestock feed. African Journal of Agricultural Research 4: 633-641

Van Soest P J (1963). The use of detergents in the analysis of fibrous feeds. II. A rapid method for determination of the fiber and lignin. JAOAC 46: 829-835

Yolcu H \& Tan M (2008). General view to Turkey forage crops cultivation. Tarım Bilimleri Dergisi-Journal of Agricultural Science 14: 303-312

Zhu Y, Bai C S, Guo X S, Xue Y L \& Ataku K (2011). Nutritive value of corn silage in mixture with vine peas. Animal Production Science 51: 1117-1122 